\title{
The influence of nonsinusoidal supply voltage on the amount of power consumption and electricity meter readings
}

\author{
Vitalii Volokhin', \\ Illia Diahovchenko', \\ Viktoriia Kurochkina $^{1}$, \\ Martin Kanálik² \\ ${ }^{1}$ Sumy State University, \\ Rymskogo-Korsakova St. 2, 40007 Sumy, \\ Ukraine \\ E-mail ilya.dyagovchenko@gmail.com \\ ${ }^{2}$ University of Košice, \\ Letná St. 9, 04200 Košice, Slovakia
}

\begin{abstract}
During electricity generation, transformation, distribution and consumption, distortions of voltage and current sinusoidal signals occur. Most consumers are non-linear, and a significant content of higher harmonics emerges when they are connected to the supply grid. The algorithms of modern electricity meters take into account most of higher harmonics, whilst with some fallibilities. However, when supply voltage and current have the same amplitude and a various harmonic composition, the readings of electricity meters can vary greatly. This article describes how the harmonic composition of supply voltage and current affects the readings of electricity metering devices. The analysed ratios do not depend on the amplitude of supply voltage.
\end{abstract}

Keywords: electric energy meter, harmonics, voltage, current, readings

\section{INTRODUCTION}

When accounting for electric energy consumption, main's voltage signal is considered to have the shape of a sine wave. The true voltage produced by generators in power plants is different from strictly sinusoidal. Additional distortions are made by power consumers (current collectors) with nonlinear load. The single-phase power consumers include:

- pulse power supplies (PPS),

- electronic ballasts of fluorescent lamps,

- small uninterruptible power supplies (UPS),

- computers, etc.

Three-phase power consumers include:
- variable speed drives,

- large switch mode power supplies (SMPS), etc. [1].

The nature of the current consumed by impulsive load causes sine wave voltage deformation applied to load terminals. Sine wave voltage becomes "flat" as voltage drop increases across the internal circuit resistance at the moment of current pulse [2].

Thus, its form approximates to trapezoidal (keystone-shaped).

The purpose of this article is to determine the effect of a supply voltage waveform on power metering devices. Three basic forms of voltage shape are under consideration: trapezoidal, 
triangular and rectangular. It should be noted that the last two are particular cases of a trapezoidal-shaped sine curve.

\section{THE DEFINITION OF THE SUPPLY VOLTAGE EQUATION}

Voltage is a finite periodic function which receives identical values at regular time intervals. Therefore, it can be expanded in a trigonometric Fourier series [11]:

$$
\begin{aligned}
& u(t)=U_{0}+U_{m 1} \cdot \sin \left(\omega t+\varphi_{1}\right)+ \\
& +U_{m 2} \cdot \sin \left(2 \omega t+\varphi_{2}\right)+ \\
& +U_{m 3} \cdot \sin \left(3 \omega t+\varphi_{3}\right)+\ldots= \\
& =U_{0}+\sum_{n=1}^{n=\infty} U_{m n} \sin \left(n \omega t+\varphi_{n}\right),
\end{aligned}
$$

where $n$ is the number of the harmonic component, $U_{n}=\frac{U_{m n}}{\sqrt{2}}$ is $n$-th harmonic effective voltage value, $U_{m n}$ is $n$-th harmonic amplitude value, and $U_{0}$ is voltage constant component value.

In some cases, a periodic function can be presented as a binary series. For this purpose, each component of the equation (1) needs to be expanded by the formula

$$
\begin{aligned}
& U_{m n} \sin \left(n \omega t+\varphi_{n}\right)==U_{m n} \cos \varphi_{n} \sin n \omega t+ \\
& +U_{m n} \sin \varphi_{n} \cos n \omega t .
\end{aligned}
$$

By equating

$$
U_{m n} \cos \varphi_{n}=U_{m n}^{\prime} \text { and } U_{m n} \sin \varphi_{n}=U^{\prime \prime}{ }_{m n}{ }^{\prime}
$$

we can represent Fourier series in the form of a double series of sines and cosines, which do not have any phase shift at the origin of coordinates:

$$
\begin{aligned}
& u(t)=U_{0}+U_{m 1}^{\prime} \cdot \sin \omega t+U_{m 2}^{\prime} \cdot \sin 2 \omega t+ \\
& +U_{m 3}^{\prime} \cdot \sin 3 \omega t+\ldots+U_{m n}^{\prime} \cdot \sin n \omega t+\ldots+ \\
& +U_{m 1}^{\prime} \cdot \cos \omega t+U^{\prime \prime}{ }_{m 2} \cdot \cos 2 \omega t \\
& +U^{\prime \prime}{ }_{m 3} \cdot \cos 3 \omega t+\ldots+U^{\prime \prime}{ }_{m n} \cdot \cos n \omega t+\ldots
\end{aligned}
$$

Let us consider the case when the average ordinate voltage (effective value) for the whole period equals zero. In this case, Fourier series will not contain a constant voltage component $U_{0}[4]$. This can be easily explained by the fact that the average value of voltage waveform ordinates must be equal to the average value of the summands of Fourier series for the whole period. As long as the average number of sinusoid ordinates for the entire number of periods is equal to zero, then the average value of the voltage waveform ordinates will be equal to the DC component value:

$$
\begin{aligned}
& U_{0}=\frac{1}{2 \pi} \int_{0}^{2 \pi} u(t) d t= \\
& =\frac{1}{2 \pi} \int_{0}^{2 \pi}\left[U_{0}+\sum_{n=1}^{n=\infty} U_{m n} \sin \left(n \omega t+\varphi_{n}\right)\right] d t= \\
& =\frac{U_{0}}{2 \pi} \int_{0}^{2 \pi} d t+\sum_{n=1}^{n=\infty} \frac{U_{m n}}{2 \pi n} \int_{0}^{2 \pi} d t \sin \left(n \omega t+\varphi_{n}\right) d t .
\end{aligned}
$$

It follows that if the $x$-axis coincides with the centerline, $U_{0}=0$. Then, the voltage curve can be represented by the equation:

$$
\begin{aligned}
& u(t)=U_{m 1} \cdot \sin \left(\omega t+\varphi_{1}\right)+U_{m 1} \cdot \sin \left(2 \omega t+\varphi_{2}\right)+ \\
& +U_{m 1} \cdot \sin \left(3 \omega t+\varphi_{3}\right)+\ldots=\sum_{n=1} U_{m n} \sin \left(n \omega t+\varphi_{n}\right) .
\end{aligned}
$$

In high currents technique you often have to deal with electromotive force (EMF) and currents whose curves are symmetrical relative to the $x$-axis. That is, their ordinates at any time (from 0 to $\pi$ ) starting from the beginning of the period and from the beginning of the second half period (from $T$ to $2 T$ ) are equal in magnitude but opposite in sign:

$$
u(t)=-u\left(t+\frac{T}{2}\right) .
$$

In such a curve, starting from the beginning of the first and second half period, a DC component and even-order harmonics are not available [4]. Assume that the voltage curve is also symmetrical relative to the axis passing through the middle between the intersection of the curve with the abscissa axis, namely

$$
\begin{aligned}
& u(t)=u(\pi-t)=-u(-t) \\
& \text { or } \\
& U_{m 1}^{\prime} \cdot \sin \omega t+U_{m 3}^{\prime} \cdot \sin 3 \omega t+U_{m 5}^{\prime} \cdot \sin 5 \omega t+\ldots \\
& U_{m(n+1)}^{\prime} \cdot \sin (\mathrm{n}+1) \omega t+\ldots+U_{m 1}^{\prime} \cdot \cos \omega t+ \\
& U^{\prime \prime}{ }_{m 3} \cdot \cos 3 \omega t+U^{\prime \prime}{ }_{m 5} \cdot \cos 5 \omega t+\ldots \\
& U_{m(n+1)}^{\prime} \cdot \cos (\mathrm{n}+1) \omega t=-U_{m 1}^{\prime} \cdot \sin (-\omega t)- \\
& U_{m 3}^{\prime} \cdot \sin (-3 \omega t)-U_{m 5}^{\prime} \cdot \sin (-5 \omega t)-\ldots
\end{aligned}
$$




$$
\begin{aligned}
& U_{m(-2 n-1)}^{\prime} \cdot \sin (-2 \mathrm{n}-1) \omega t-\ldots-U_{m 1}^{\prime \prime} \cdot \cos (-\omega t)- \\
& U^{\prime \prime}{ }_{m 3} \cdot \cos (-3 \omega t)-U^{\prime \prime}{ }_{m 5} \cdot \cos (-5 \omega t)-\ldots \\
& -U^{\prime \prime}{ }_{m(-2 n-1)} \cdot \cos (-2 n-1) \omega t
\end{aligned}
$$

In such a curve, the main sine wave and all the harmonics cross the $x$-axis in one point. As the sine changes its sign when altering the argument (an odd function) but cosine does not change (an even function), then the condition (8) can be fulfilled only in case when

$$
U^{\prime \prime}{ }_{(n+1)}=U_{(n+1) m} \sin \varphi_{n}=0 .
$$

Fourier series takes the form:

$$
\begin{aligned}
& u(t)=U_{m 1} \cdot \sin \omega t+U_{m 3} \cdot \sin 3 \omega t+ \\
& +U_{m 5} \cdot \sin 5 \omega t+\ldots=\sum_{n=0}^{n=\infty} U_{m(2 n+1)} \sin (2 n+1) \omega t .
\end{aligned}
$$

Let us consider a few periodic voltage functions which meet the conditions (6) and (7).

\section{TRAPEZOIDAL VOLTAGE WAVEFORM}

Let us consider the case when a voltage curve has a shape close to trapezoidal (Fig. 1). For both halves of the period it is symmetrical with respect to the midline, relative to the points of intersection with the abscissa axis. If such a point is chosen as the origin of coordinates, we can restrict our consideration to only one-fourth of the period and find only $U_{m n}^{\prime}$ values, because $U^{\prime \prime}{ }_{m n}=0$.

In its inclined part from $t=0$ to $t=a$ the curve can be represented by the equation

$$
u(t)=B \cdot \frac{\omega t}{a}
$$

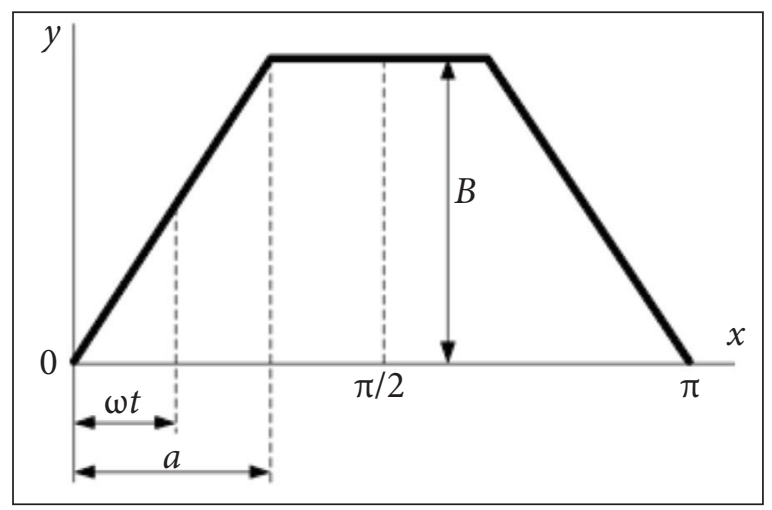

Fig. 1. Trapezoidal voltage waveform and in the straight part from $t=$ a to $t=\frac{\pi}{2}-$ by
the equation

$$
u(t)=B .
$$

By inserting (10) and (11) into the equation (9) within the limits from 0 to $\pi / 2$, we obtain

$$
\begin{aligned}
& U_{(n+1)}^{\prime}=\frac{4}{\pi} \int_{0}^{\frac{\pi}{2}} u(t) \sin n t d t= \\
& =\frac{4}{\pi} \int_{0}^{a} B \frac{t}{a} \sin n t d t+\frac{4}{\pi} \int_{a}^{2} B \sin n t d t .
\end{aligned}
$$

After several transformations and substitutions $n=1,3$, etc., for trapezoidal-shaped voltage we will obtain:

$$
\begin{aligned}
& u(t)=\frac{4 B}{a \pi}\left(\sin a \sin \omega t+\frac{1}{9} \sin 3 a \sin 3 \omega t+\right. \\
& \left.+\frac{1}{25} \sin 5 a \sin 5 \omega t+\ldots+\frac{1}{n^{2}} \sin n a \sin n \omega t\right) .
\end{aligned}
$$

When

$$
\begin{aligned}
& \omega=\frac{2 \pi}{T}, \\
& u(t)=\frac{4 B}{a \pi} \sum_{n=1}^{\infty} \frac{1}{n^{2}} \sin n a \sin n \omega t .
\end{aligned}
$$

\section{TRIANGULAR VOLTAGE WAVEFORM}

A triangular voltage waveform (Fig. 2) is a particular case of a trapezoidal under the condition $a=\frac{\pi}{2}$. Herewith, the amplitude signal is equal to $B$.

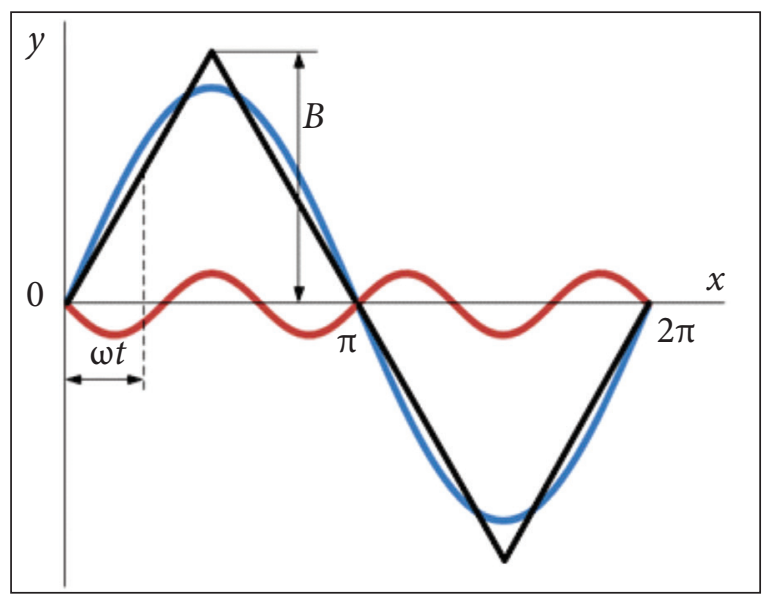

Fig. 2. Triangular voltage waveform 
For triangular voltage waveform time dependence will be presented as:

$$
\begin{aligned}
& u(t)=\frac{8 B}{\pi^{2}}\left(\sin \omega t-\frac{1}{9} \sin 3 \omega t+,\right. \\
& \left.+\frac{1}{25} \sin 5 \omega t-\ldots+\frac{(-1)^{-\frac{n-1}{2}}}{n^{2}} \sin n \omega t\right) . \\
& u(t)=\frac{8 B}{\pi^{2}} \sum_{n=1}^{\infty} \frac{(-1)^{-\frac{n-1}{2}}}{n^{2}} \sin n \omega t .
\end{aligned}
$$

\section{RECTANGULAR VOLTAGE WAVEFORM}

A rectangular voltage waveform (Fig. 3) can be obtained as a special case of a trapezoidal one in the absence of $a$.

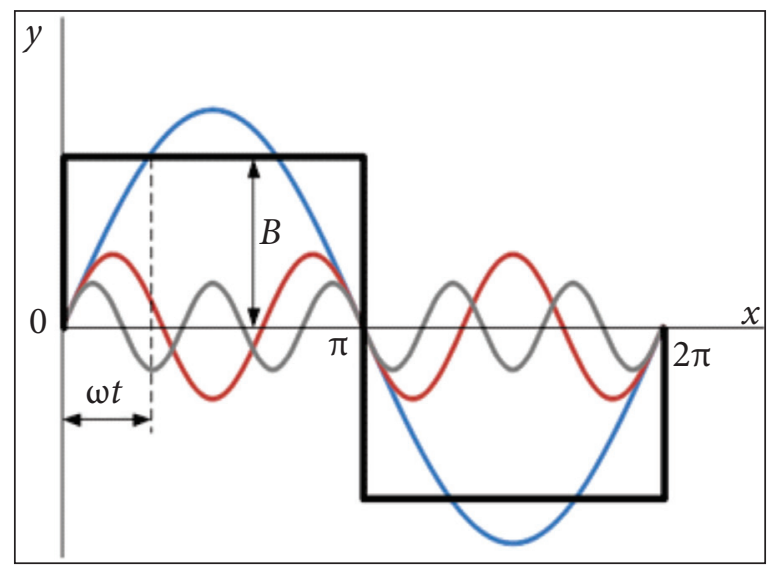

Fig. 3. Rectangular voltage waveform

The dependence on time for rectangular voltage waveform is given below:

$$
\begin{aligned}
& u(t)=\frac{4 B}{\pi}\left(\sin \omega t+\frac{1}{3} \sin 3 \omega t+\frac{1}{5} \sin 5 \omega t+\ldots\right. \\
& \left.+\frac{1}{n} \sin n \omega t\right)
\end{aligned}
$$

or

$$
u(t)=\frac{4 B}{\pi} \sum_{n=1}^{\infty} \frac{1}{n} \sin n \omega t .
$$

\section{THE DETERMINATION OF POWER}

The real power of periodic AC arbitrary waveform current is defined as the average power over the whole period:

$$
P=\frac{1}{T} \int_{0}^{T} u(t) i(t) d t
$$

where $T$ is the period, sec.

We know voltage waveforms. They are defined by the equations (14), (16) and (18). There remains to determine the current function.

By the principle of superposition, the instantaneous current in a steady state circuit is equal to the total of instantaneous current values which would occur under the independent action of the DC component, fundamental sinusoid and higher harmonics singly.

Suppose we have an electrical circuit with the load of active-reactive character. With the constant values of active resistance $R$, inductance $L$ and capacitance $C$, the operating voltage breaks down into three components at any moment: ohmic voltage drop, inductive EMF, and capacitive EMF:

$$
u=i R+L \frac{d i}{d t}+\frac{1}{C} \int_{0}^{t} i d t
$$

In the absence of a constant component and even harmonics (as in our case) the effective current value is

$$
i=i_{1}+i_{3}+i_{5}+\ldots+i_{n+1} \text {. }
$$

The actual current in a circuit can be represented by the equation:

$$
i=\sum_{n=1}^{n=\infty} \frac{U_{m n} \sin \left(n \omega t+\psi_{n}-\varphi_{n}\right)}{\sqrt{R^{2}+\left(n \omega L-\frac{1}{n \omega C}\right)^{2}}},
$$

where

$$
\operatorname{tg} \varphi_{n}=\frac{n \omega L-\frac{1}{n \omega C}}{R}-\text { power factor. }
$$

Let us consider the electric network of industrial frequency $(50 \mathrm{~Hz})$ with the following $\mathrm{AC}$ load parameters:

- active impedance $R=100 \mathrm{Ohms}$,

- inductance $L=500 \mathrm{mH}$, and

- capacitance $C=100 \mu \mathrm{F}$.

The peak value of the voltage wveform is assumed to be equal $220 \cdot \sqrt{2}$. For the trapezoidal-shaped curve the value is $a=0.8$. 
Consider the three forms of the supply voltage curve. Their shapes are shown in Fig. 4.

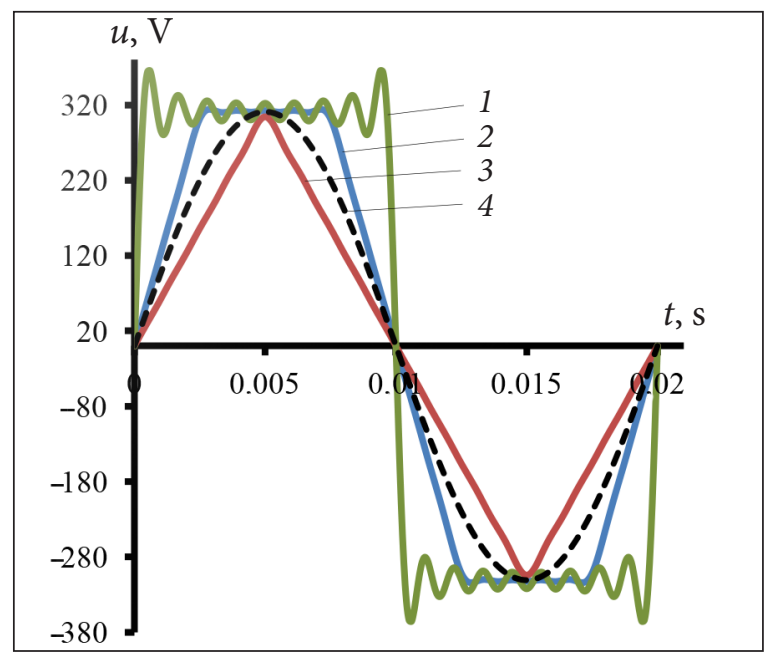

Fig. 4. Voltage curves: 1 - rectangular, 2 - trapezoidal, 3 - triangular, 4 - ideal sine wave

Since the impedance for each of the harmonics will have its own special value and a shear angle, then the components of current sine waves will have the amplitudes not proportional to the amplitudes of the components of voltage (power supply) harmonics [4]. It follows that the shape of the current curve may significantly differ from the voltage waveform. Current curves in the electric circuit with the specified parameters will have the form represented in Fig. 5.

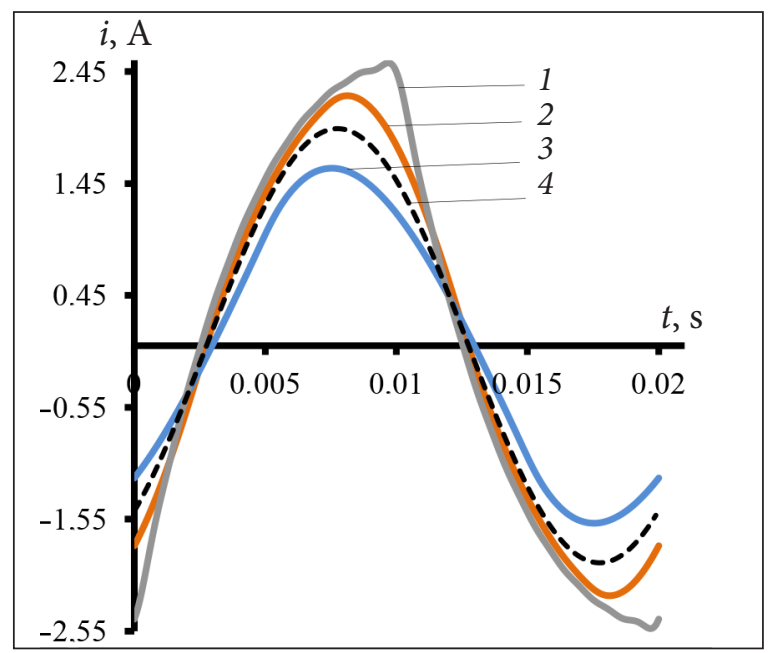

Fig. 5. Current curves: 1 - rectangular, 2 - trapezoidal, 3 - triangular, 4 - ideal sine wave
The active power of periodic alternating currents of arbitrary shape is determined in accordance with the formula (19):

- for trapezoidal voltage waveform: $P_{1}=245,935 \mathrm{~W}$,

- for triangular voltage waveform: $P_{2}=123,982 \mathrm{~W}$,

- for rectangular voltage waveform: $P_{3}=310,11 \mathrm{~W}$.

The power of the ideal sinusoidal voltage and current will make: $P_{\sin }=188,419 \mathrm{~W}$.

Let us further determine the apparent power. It's equal to the effective value of voltage multiplied by the effective value of current:

$$
S=U \cdot I V A,
$$

where $U$ is the effective value of voltage

$$
U=\sqrt{\frac{1}{T} \int_{0}^{T} u^{2}(t) d t} B
$$

$I$ is the effective value of current

$$
I=\sqrt{\frac{1}{T} \int_{0}^{T} i^{2}(t) d t} A
$$

The reactive component can be defined from power triangle:

$$
Q=\sqrt{S^{2}-P^{2}} \text { Var. }
$$

The results of calculations are shown in Table 1.

Table 1. The calculations of power values

\begin{tabular}{ccccc}
\hline Waveform & Active P, W & $\begin{array}{c}\text { Reactive Q, } \\
\text { Var }\end{array}$ & $\begin{array}{c}\text { Apparent S, } \\
\text { VA }\end{array}$ \\
\hline Trapezoidal & 245.935 & 311.042 & 396.524 \\
\hline Triangular & 123.982 & 156.947 & 200.01 \\
\hline Rectangular & 310.11 & 444.147 & 541.697 \\
\hline Pure sinusoidal & 188.419 & 235.994 & 301.985 \\
\hline
\end{tabular}

The power curves are shown in Fig. 6.

In accordance with $[9,12]$, state-of-the-art electronic meters can take account of electric energy which is consumed by the load at the frequency of fundamental and higher harmonics.

For active energy meters: 


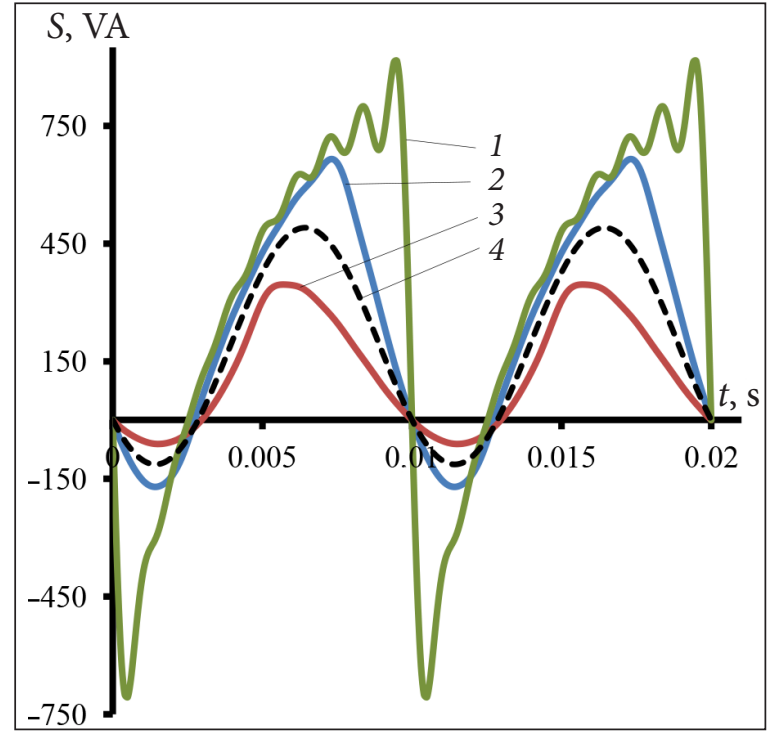

Fig. 6. Apparent power curve shapes: 1 - rectangular, 2 - trapezoidal, 3 - triangular, 4 - ideal sine wave

$$
W_{P}=\Sigma U_{n} \cdot I_{n} \cdot \cos \varphi_{n} \cdot t=\sum_{n=0}^{40} P_{n} \cdot t .
$$

For reactive energy meters:

$$
W_{Q}=\Sigma U_{n} \cdot I_{n} \cdot \sin \varphi_{n} \cdot t=\sum_{n=0}^{40} Q_{n} \cdot t,
$$

where $t$ is current time; the value of phase-shift angle $\varphi_{n}$ is determined from the expression (23) separately for each harmonic.

Provided $t=$ const, the electric energy consumed in electrical network is proportional to power magnitude:

$$
W_{P} \equiv P, \mathrm{~W}_{Q} \equiv Q
$$

Using the data of Table 1, for trapezoidal voltage waveform the amount of electric energy input (for the specified electrical network) will be $31.31 \%$ higher than with sinusoidal supply voltage; for triangular 50.99\% lower, and for rectangular $79.38 \%$ higher. In these calculations the amount of 'pure sinusoidal' energy is regarded as $100 \%$.

The readings of active energy meters operating by the formula (24) show 30.52\% higher consumption with trapezoidal voltage waveform, $51.97 \%$ lower with triangular, and $64.59 \%$ higher with rectangular.

Reactive power meters exercising registration by the formula (25) will show $31.8 \%$ higher consumption with trapezoidal voltage waveform, $50.37 \%$ lower with triangular, and $88.2 \%$ higher with rectangular.

\section{CONCLUSIONS}

The presence of higher harmonic distortions significantly affects the amount of electricity which is consumed by the mixed load (RLC-circuit). If the grid voltage has a shape closed to trapezoidal or rectangular, the load takes more power (real and reactive as well) compared with sinusoidal voltage waveform of the same amplitude. Modern electricity meters can account for electricity extra-intake caused by the presence of higher harmonics. Therefore, the consumer will have to pay more for electricity.

Active power meters operating by equation (24) will show nearly $1 / 3$ higher consumption in case of trapezoidal voltage waveform and nearly $2 / 3$ higher in case of rectangular voltage waveform.

The readings of reactive power meters operating by equation (25) will be nearly $1 / 3$ higher if voltage waveform is trapezoidal and nearly $9 / 10$ higher when voltage waveform is rectangular.

For triangular waveform the opposite situation is observed: active and reactive energy meters will register approximately 1/2 less energy consumption compared with the condition of pure sinusoidal voltage.

The above-mentioned calculated ratios do not depend on supply voltage amplitude. For the trapezoidal waveform, meter readings rely on the length of the trapezoid angled face (the length on the x-axis) designated by $a$ in Fig. 1 . If $a$ tends to zero, then electricity consumption will increase, while if it tends to $\pi / 2$, electricity consumption will decrease.

Received 12 July 2016 Accepted 12 December 2016

\section{References}

1. Chapman D. Harmonics: Causes and Effects. ECI Publication No. Cu0119, 2011.21 p.

2. Grigor'ev O., Petuhov V., Sokolov V., Krasilov I. Vysshie garmoniki v setjah jelektrosnabzhenija $0,4 \mathrm{kV}$ [Higher harmonics in supply networks of $0.4 \mathrm{kV}$ ]. Novosti jelektrotehniki. 2002. No. 6(18). 
3. Campbell G., Foster R. Fourier Integrals for Practical Applications. New York: D. Van Nostrand Company Inc., 1948. 477 p.

4. Krug K. A. Osnovy elektrotekhniki. Teoriya peremennyh tokov [The basis of electrical engineering. Theory of alternating currents] in 2 vols, Vol. 2, 6th ed. completely redesigned. Moscow, Leningrad, Gosudarstvennoe ehnergeticheskoe izdatel'stvo Publ., 1946. 637 p.

5. Fassbinder S. Power Quality Application Guide. Harmonics: Capacitors in Harmonic-Rich Environments. Dusseldorf: Deutsches Kupferinstitut, 2004. $16 \mathrm{p}$.

6. Fassbinder S. Power Quality Application Guide. Harmonics: Passive Filters. Dusseldorf: Deutsches Kupferinstitut, 2003. 12 p.

7. IEEE Std 1459-2010 (March 2010). Definitions for the measurement of electric power quantities under sinusoidal, nonsinusoidal, balanced or unbalanced conditions. IEEE Std, $40 \mathrm{p}$.

8. IEEE Working Group on Nonsinusoidal Situations, Practical Definitions for Powers in Systems with Nonsinusoidal Waveforms and Unbalanced Loads. IEEE Transactions on Power Delivery. Vol. 11. No. 1. Jan. 1996. P. 79-101.

9. Baryshev U. A., Vostroknutov N. N. Osnovnye svojstva pogreshnostej sovremennyh schetchikov ehlektricheskoj ehnergii [The basic properties of the errors of modern electricity meters]. Kompetentnost. 2015. No. 4. P. 42-49.

10. IEEE Recommended Practice and Requirements for Harmonic Control in Electric Power Systems. March 2014. IEEE Standard 519. 29 p.
11. Körner T. W. Fourier Analysis. Cambridge: Cambridge University Press, 1988. 591 p.

12. Watt-Hour Meter Maintenance and Testing. Denver, Colorado: United States Department of The Interior Bureau of Reclamation, 2000. 72 p.

\section{Vitalii Volokhin, Illia Diahovchenko,}

Viktoriia Kurochkina, Martin Kanálik

\section{NESINUSINĖS MAITINIMO İTAMPOS İTAKA ENERGIJOS SUVARTOJIMUI IR SKAITIKLIO RODMENIMS}

\section{Santrauka}

Generuojant, transformuojant, skirstant ir naudojant elektros energiją neretai iškraipomi sinusiniai ịtampos ir srovès signalai. Vartotojų apkrovos dažniausiai yra netiesinès, ir didžiąją visų iškraipymų dalị sudaro būtent tokių apkrovų ịjungimas ị tinklą. Šiuolaikiniai elektros skaitikliai daugumą harmonikų atpažįsta ir $\mathfrak{i}$ juos atsižvelgia, dažniausiai su priimtinomis paklaidomis. Tačiau jeigu maitinimo įtampos ir srovès amplitudès tokios pačios, o harmonikų sudètys skirtingos, skaitiklių rodmenys gali labai ịvairuoti. Straipsnyje aprašoma, kaip maitinimo įtampos ir srovès harmonikų sudètis veikia elektros skaitiklių rodmenis. Išnagrinèti santykiai nepriklauso nuo maitinimo ịtampos amplitudès dydžio.

Raktažodžiai: elektros energijos skaitiklis, harmonikos, ịtampa, srovè, rodmenys 